\title{
MAGYARORSZÁG: TÁRSADALOM, ÁLLAM, GAZDASÁG ÉS REGIONÁLIS ÁTALAKULÁS
}

\author{
Hajdú Z. (1993) Hungary: Society, State, \\ Economy and Regional Structure in Transition \\ Centre for Regional Studies, Pécs, 294 o.
}

A változások korát éljük. A néhány éve, évtizede még elképzelhetetlennek tünõ átalakulások ma egymást követik a világban. Hosszasan lehetne sorolni a példákat a Szovjetunió felbomlásától a szocializmus összeomlásán keresztül új államok kialakulásáig.

Nem csekély mértékben érezzük a változásokat Magyarországon is. Az élet, a gazdaság minden területét áthatják, kit kedvezôen, kit kedvezôtlenül érintve. A gazdaságban a tervutasításos rendszert felváltja a piac által befolyásolt irányítás, a demokrácia intézményei teret nyernek hazánkban. Mint minden változásnak, ennek is vannak nyertesei és vesztesei. Komoly gondokat, válsághelyzeteket teremt az átalakulás és ugyanakkor elônyösen is hat az ország gazdasági, társadalmi és politikai életére.

Mindezen változásokat elemzi a Hajdú Zoltán szerkesztésében, a Magyar Tudományos Akadémia Regionális Kutatások Központja gondozásában a közelmúltban megjelent, Hungary: Society, State, Economy and Regional Structure in Transition (Magyarország: társadalom, állam, gazdaság és regionális átalakulása) címũ kötet.

A kötetben megjelent tanulmányok, mint azt a cím is jelzi, mindenkor a változásokra fektetik a hangsúlyt. Visszatekin- tenek a történelmi háttérre, majd a jelenlegi helyzet elemzésével folyamatukban mutatják be a változásokat. Szinte minden esetben részletesen elemzik az elmúlt néhány évtized történéseit és hatásukat a mai állapotokra.

Négy évtized örökségén néhány év vagy még rövidebb idố alatt kellett, vagy kellene változtatni. Nyilvánvaló, hogy ez az ,,erôltetett menet" fájdalmas áldozatokkal jár. Találóan hasonlítja Illés Iván írásában (The Main Features and Problems of Political-Economic Transition in Hungary; A politikai-társadalmi változások fổbb jellemvonásai és problémái Magyarországon) a magyar gazdaságot olyan öttusa versenyzôjéhez, ahol lôni, vívni, lovagolni, úszni és futni egyszerre kell.

A könyv részletesen foglalkozik a mai magyar gazdaságot, társadalmat sújtó legégetôbb problémákkal, az elônytelen gazdasági szerkezettel, az ipari termelés stagnálásával, illetve visszaesésével, a mezôgazdaság gondjaival, a munkanélküliséggel, az infrastruktúra, a közlekedés, hírközlés hiányosságaival, a társadalom polarizálódásával, a környezet minôségének romlásával, hogy csak néhányat említsünk a számos gond közül.

Évekkel ezelôtt felismert és sajnos teljes egészében máig nem megoldott szükségszerüség hazánk iparszerkezetének megújí- 
tása, az adottságoknak jobban megfelelô struktúra kialakítása. Bartke István írása (Restructuring of Hungarian Industry and Its Regional Effects; A magyar ipar szerkezetváltása és ennek regionális hatásai) ezzel a témakörrel foglalkozik. Részletes területi és iparágak szerinti bontásban kíséri figyelemmel a magyar ipar fejlôdését és elemzi a mai problémák okait, az elônytelen iparszerkezet negatív hatásait és annak területi vonatkozásait, a depressziós térségek kialakulásának okait.

$\mathrm{Az}$ összes, hazánkat jelenleg sújtó gond közül talán a munkanélküliség az, amely legérzékenyebben érinti a társadalmat. Unemployment as a New Phenomenon of the Transition (A munkanélküliség mint a változás új jelensége) címmel találjuk a kötetben Dövényi Zoltán tanulmányát. Azt, hogy e téma megkülönböztetett figyelmet érdemel, mi sem bizonyítja jobban, mint hogy a cikk tanúsága szerint a mai magyar társadalom komolyabb problémának tartja a munkanélküliséget, mint akár a megélhetési gondokat, a szegénységet vagy a lakáshelyzetet. A cikk a magyar munkanélküliség történetét elemzi a szocializmusban deklarált ,,teljes foglalkoztatottságtól" egészen a mai - finoman fogalmazva - nem egészen teljes foglalkoztatottságig. A rejtett és el nem ismert munkanélküliségbốl a nyílt és vállalt munkanélküliségbe való átmenet folyamatát tárja elénk, elôrevetítve a jövõ folyamatait, történéseit is.

A munkanélküliség terjedése felszínre hozza mindazokat a feszültségeket, amelyek az elszegényedõ és a feltörekvõ rétegek között fennállnak, fokozottan hozzájárul a társadalom polarizálódásához. Bôhm
Antal írása (The Hungarian Society at the Start of Its Transformation Into a Market Society; A magyar társadalom a piaci társadalommá való átalakulás küszöbén) azt a folyamatot vizsgálja, hogy miként hat a rendszerváltás hazánk társadalmára, hogyan bomlik fel a korábbi „homogén" társadalom, s milyen változásokon megy keresztül Magyarország társadalmi struktúrája. Vizsgálja az írás a magyar társadalom általános jellemzõit, mint a népességszám alakulását, annak korcsoportok szerinti megoszlását, iskolázottsági adatokat stb., csakúgy, mint a polgári társadalom kialakulását gátló tényezôket és azok hatásait. Szintén kutatja a cikk a középosztály tulajdonképpeni hiányának okait és következményeit.

A középszint hiányával a kötet több tanulmánya foglalkozik. (A probléma aktuális jellegét jól mutatja az ez év március 4-5-én Székesfehérvárott megrendezett, A középszintũ közigazgatás reformja Magyarországon címũ konferencia.) Pálné Kovács Ilona írásában (The Current Problems of Local/Regional Government in Hungary; A helyi/regionális önkormányzat jelenlegi problémái Magyarországon) a rendszerváltás következményeirôl, a korábbi centralizált modell megszunnésérốl, a regionális kormányzat szerkezetérōl, az önkormányzatok és a decentralizált szervek közti kapcsolatról, a kormányzati középszintrôl, a kis- és mezotérségek felbomlásáról, az önkormányzatok és a helyi társadalom viszonyáról szól.

A magyar gazdaság fellendülésének egyik közismert korlátja az infrastruktúra alacsony fejlettségi színvonala. Erdôsi Ferenc írása (Formation of the Regional 
Structure of Traffic and Communications; A közlekedés és a távközlés regionális szerkezetének alakulása) kitér a nemzetközi szállítási kapcsolatok megváltozására és annak következményeire (némi történeti háttérrel illusztrálva a folyamatot), egyes fontos közlekedéspolitikai eseményekre (Duna-Majna-Rajna-csatorna megnyitása és lehetséges hatása, a Duna szerepének felértékelödése), illetve problémákra (déli autópálya), a közlekedési infrastruktúra fejlődésére és közlekedéspolitikánk jellemzöire. Említést tesz az írás a magyar közlekedéspolitika elött álló feladatokról, a tömegközlekedés nehézségeirôl is csakúgy, mint a távközlési rendszer fejlôdéséröl, ezáltal a regionális különbségek kisebbedésérõl. A regionális megközelítés egyébként, mint a kötet nem egy tanulmányát, ezt az írást is végigkíséri. Végezetül a következõ évtizedek távközlésének lehetséges regionális hatásait taglalja a tanulmány.

Említettük már, hogy minden változás, minden átalakulás gyõzteseket és veszteseket eredményez. Sajnos igen sok esetben a természet, a környezet is a vesztesek közé tartozik. Míg a fejlett gazdaságú és magas életszínvonalú országok megengedhetik maguknak, hogy beruházási, ipartelepítési döntéseiket egyre inkább a környezetvédelem igényei szerint alakítsák, a szegényebb, adóssággal küszködố országok számára gyakran nem mutatkozik más lehetôség, mint a termelés és ezzel a valutabevételek minden eszközzel történõ növelése. A költségeket pedig igen komoly mértékben csökkenteni lehet, mint ahogy azt a magyar gyakorlat számtalan esetben bebizonyitotta, a környezetvédelmi beru- házások elmulasztása révén.

A könyvben két tanulmány foglalkozik közvetlenül a környezeti problémákkal. Enyedi György írásában (Sustainable Regional Development in Hungary; Fenntartható regionális fejlődés Magyarországon) a környezet állapotának fokozatos romlásáról, annak okairól szól, valamint a fenntart-ható fejlődés koncepciójának alkalmazhatóságáról és arról, hogy az egyes kormányzati elemek tevékenységét hogyan lehet összehangolni a fenntartható fejlődéssel. Említést tesz az írás a piaci szabályo-zás elổnyeirõl az adminisztratív szabályo-zás ellenében, és kiemeli a magyar-országi politikai változások kedvezõ hatásait a fenntartható fejlôdés szempontjából. A cikk a fenntartható regionális fejlődés jellemzőivel, feltételrendszerének megfogalmazásával zárul.

Fodor István tanulmányában (The Economic Dilemmas of Ecological CrisisManagement; Az ökológiai válságkezelés gazdasági dilemmái) a Kelet-Európát sújtó ökológiai válság kezelésének szükségességéröl olvashatunk. Az írás az OTKA és PHARE által támogatott kutatási projekt ismertetése, amely azt vizsgálta, mennyiben felelnek meg a magyar vállalatok a PHARE követelményeinek. A tanulmány részletesen leírja az alanyok kiválasztásának és az értékelésnek a szempontjait, amiáltal akár útmutatóul is szolgálhat késôbbi hasonló tanulmányok számára.

Pusztán a régi lebontásával nem teremtjük meg a lehetôségét az új kialakulásának. Nyilvánvaló, hogy az átalakulásnak magával kell vonnia a megfelelö intézményrendszerek át-, vagy egyáltalán kialakulását. A könyv néhány tanulmánya a 
változások intézményi hátterét tanulmányozza.

Ádám Antal írása, amely a Transformation of the Constitutional Model (Az alkotmányos modell átalakulása) címet viseli, részletesen tárgyalja az átalakulás jellemzổ vonásait évtizedekre visszanyúló történelmi hátteret adva, sôt helyenként évszázadokkal ezelốtti politikại eseményekkel támasztva alá mondanivalóját. Elemzi a központi kormányzati szervek rendszerét, külön tárgyalva a köztársasági elnök és a parlament, valamint a köztársasági elnök és a kormány kapcsolatát, rámutat a jelenlegi ellentmondásokra és problémákra. Az Alkotmánybíróság tevékenysége néhány csomópontjának megvilágításával fejezôdik be az írás.

A gazdaság megújulásának egyik alapvetô feltétele a megfelelố pénzügyi és hitelrendszer kialakulása. Az egyszintũ bankrendszer kétszintûvé tételével, a régi bankrendszer elemeivel és funkcióikkal, az egyszintũ bankrendszer felbomlásának elózményeivel, az új rendszer szereplốivel és feladataival foglalkozik Lengyel Imre The Hungarian Banking System in Transition (A magyar bankrendszer átalakulása) címet viselổ tanulmánya.

A változások a társadalom jövõje szempontjából talán legfontosabb szférát, az oktatást sem hagyták érintetlenül. A korábbi uniformizált iskolarendszer néhány kísérleti iskolával, sokkal sokrétũbb, sokkal nagyobb választást biztosító szisztémának adja át a helyét. Az oktatásügy változását kíséri figyelemmel Forray $R$. Katalin Systemic Change in Educational Policy (Rendszerváltás az oktatáspolitikában) címũ írása. Az iskoláztatás általános kérdéseivel foglalkozik a tanulmány, valamint a múlt és a ma iskolarendszerével, majd a régi, hagyományosnak tekintett iskolai formák újraéledésével. A regionális problémák sem kerülték el a szerzõ figyelmét, $s$ olvashatunk az iskoláztatás és a demográfiai kérdések kapcsolatáról is. A változások fỏ trendjeinek vizsgálatával, valamint a problémák és a kilátások felvázolásával zárul a tanulmány.

A könyv címében is szerepel a regionális szerkezet változása. Szinte az összes írás valamilyen formában érinti a regionalizmust, néhány pedig kimondottan ezek tanulmányozásának jegyében íródott. Ilyen tanulmány Nemes Nagy Józsefé is, a Regional Dimensions of the Hungarian Economic Transformation (A magyar gazdasági átalakulás regionális dimenziói). Figyelemmel kíséri az írás a gazdaság átalakulásának folyamatát, az elmúlt évek gazdasági változásainak pozitív és negatív tendenciáit. Vizsgálja a cégek alapításának regionális megoszlását, miszerint regionális különbségeket találunk a cégvezetés hatékonyságában is. Az írás külön fejezete foglalkozik ezzel a mutatóval. A cikk a regionális különbségek növekedésének bemutatásával zárul.

A településrendszer is magán viseli a változás jegyeit. Tóth József (Transformation Tendencies of the Hungarian System of Settlements; A magyar településrendszer átalakulási tendenciái) a második világháború utáni idôszaktól követi nyomon a településrendszer változását évtizedenkénti bontásban. Az idôbeni elemzést követôen a magyar településhálózat második világháború utáni fejlổdésének regionális sajátosságait tárja fel. Mint a kötet számos 
írása, Tóth Józsefé is a jövỗ lehetséges fejlốdési trendjeinek felvázolásával zárul, vizsgálva az egész rendszert befolyásoló változásokat, a rendszer elemeit, valamint a településszerkezeten belüli kölcsönös függõségeket.

Számtalanszor hangoztatott tény, hogy a gazdasági válságból a vállalkozások élénkülésével, az innovációk folyamatos és nagymérvũ terjedésével találhatjuk meg a kiutat. Horváth Gyula és Rechnitzer János tanulmányai (Entrepreneurship and Regional Policy in Hungary; Vállalkozás és a regionális politika Magyarországon, illetve Innovations and Regional Policy; Innovációk és regionális politika) e kérdéseknek a regionális politikával való összefüggését vizsgálják.

Rechnitzer János cikke az innovációk és a térszerkezet elemzésével, a térségeknek az innovációra való reagálásával, arra való fogékonyságukkal, az innovációk által létrejött térszerkezettel (innovációs, illetve potenciális innovációs zónák, perifériák és depressziós körzetek kialakulásával) foglalkozik. Említést tesz a centrumok és perifériák átalakulásáról csakúgy, mint az innováció-orientált regionális politikával szemben támasztott elvárásokról és az általa alkalmazható eszközökrốl, intézményekröl is.

Horváth Gyula a válság regionális dimenzióival indít, néhány válságtényezó vizsgálatával foglalkozik (mint például a munkanélküliség). A gazdasági szervezetrendszer fejlôdésével folytatja a cikket, majd rátér a vállalkozásokra, külön fejezetben foglalkozik a politikai rendszerváltást megelôzôekkel, ezt követôen az új vállalkozások területi elhelyezkedésével.

A kötet utolsó tanulmányának írója, Laczkó László (New Possibilities and the Constraints of Regional Science; A regionális tudomány új lehetôségei és korlátai). Az írás a regionális tudomány tartalmát, gyökereit és kezdeteit tárgyalja. Ezt követõen a regionális tudomány jelenlegi helyzetét elemzi Magyarországon. Említést tesz a közeljövô kilátásairól is, s végezetül „,néhány jó tanáccsal" lát el bennünket a regionális tudomány megújítása és megerôsítése érdekében. $E$ tanulmány adja a kötet zárszavát, talán nem véletlenül.

Összességében a könyv tartalmas, sokrétũ és mindenképpen széles érdeklődésre tarthat számot. Igen szemléletesen mutatja be az ország egyes régiói közti különbségeket, a Magyarországon belüli nyugat kelet, észak-dél és részben az északnyugat-délkelet dichotómiát.

A cikkek többsége jól használható térképeket, illetve táblázatokat tartalmaz, amelyek a nem szakemberek számára is könnyen befogadhatók, hasznos információk hordozói.

Raffay Zoltán 